\title{
Crystal Structures of 1-Aryl-1H- and 2-Aryl-2H-1,2,3-triazolyl Hydrazones. Conformational Consequences of Different Classical Hydrogen Bonds
}

\author{
Daniel T. G. Gonzaga, ${ }^{a}$ Fernando C. da Silva, ${ }^{a}$ Vitor F. Ferreira, ${ }^{a}$ James L. Wardell $*, b, c$ \\ and Solange M. S. V. Wardell
}
${ }^{a}$ Departamento de Química Orgânica, Instituto de Química, Universidade Federal Fluminense, Campus do Valonguinho, 24210-141 Niterói-RJ, Brazil

${ }^{b}$ Instituto de Tecnologia em Fármacos-Far-Manguinhos, Fundação Oswaldo Cruz (Fiocruz), Rua Sizenando Nabuco, 100, Manguinhos, 21041-250 Rio de Janeiro-RJ, Brazil

'Department of Chemistry, University of Aberdeen, Old Aberdeen AB24 3UE Aberdeen, Scotland, UK

${ }^{d}$ CHEMSOL, 1 Harcourt Road, AB15 5NY Aberdeen, Scotland, UK

\begin{abstract}
The crystal structures of (Z)-1-phenyl-4-[((2-phenylhydrazono)methyl)]-1H-1,2,3-triazole, (Z)-4-[(2-(2,4-dimethylphenyl)hydrazono)methyl]-2-phenyl-2H-1,2,3-triazole, $(E)-4-[(2-$ (2,4-dinitrophenyl)hydrazono)methyl]-2-phenyl-2H-1,2,3-triazole, and (E)- $N^{\prime}$-((2-phenyl-2H1,2,3-triazol-4-yl)methylene)isonicotinohydrazide dihydrate are reported. The formations of (Z)- configurations about the $\mathrm{C}=\mathrm{N}$ bonds in the first two compounds arise from the stabilizing presence of intramolecular $\mathrm{N}-\mathrm{H} \cdots \mathrm{N}$ hydrogen bonds, while in the third compound, the presence of intramolecular $\mathrm{N}-\mathrm{H} \cdots \mathrm{O}$ hydrogen bonds promotes an $(E)$ geometry. The arrangement about the $\mathrm{CONHC}=\mathrm{N}$ fragment in the hydrated acylhydrazone is $E_{C(O) N H} / E_{C=N}$ Also present in $(E)-N-((2-$ phenyl-2H-1,2,3-triazol-4-yl)methylene)isonicotinohydrazide is an interesting $\mathrm{R}_{4}^{4}(8)$ ring formed from hydrogen bonds generated from four water molecules. Significant $\pi \cdots \pi$ stacking interactions are exhibited in three compounds, but not in the least planar first compound, in which the dominant intermolecular interactions are $\mathrm{C}-\mathrm{H} \cdots \pi$ interactions. Other intermolecular interactions in one of the compounds are $\mathrm{C}-\mathrm{H} \cdots \pi$ interactions, in another compound are $\mathrm{C}-\mathrm{H} \cdots \mathrm{O}$ hydrogen bonds and $\mathrm{N}-\mathrm{O} \cdots \pi$ interactions, and in the last compound are $\mathrm{O}-\mathrm{H} \cdots \mathrm{X}(\mathrm{X}=\mathrm{O}$ and $\mathrm{N}), \mathrm{N}-\mathrm{H} \cdots \mathrm{O}$ and $\mathrm{C}-\mathrm{H} \cdots \mathrm{O}$ hydrogen bonds.
\end{abstract}

Keywords: benzotriazoles, hydrazones, acylhydrazones, hydrates, intermolecular interactions

\section{Introduction}

1,2,3-Triazole derivatives have found applications in many areas. ${ }^{1-3}$ Particularly important uses have been in the medical field, including as antiviral, ${ }^{4-6}$ antimalarial, ${ }^{7}$ antitubercular, ${ }^{8-10}$ antifungal, ${ }^{11-13}$ anti-HIV, ${ }^{14}$ $\beta$-lactamase inhibition, ${ }^{15}$ anti-epileptic, ${ }^{16}$ anti-HSV, ${ }^{17}$ anti-inflammatory, ${ }^{18}$ antimicrobial ${ }^{19,20}$ and $\alpha$-glycosidase inhibition agents. ${ }^{21-24} \mathrm{~A}$ recent $\alpha$-glycosidase inhibition study involved a number of different 1-phenyl- $1 H$ - and 2-phenyl-2H-1,2,3-triazolyl derivatives. ${ }^{24}$ See Figure 1 for the tautomeric forms of the parent compounds: $1 H-1,2,3-$ triazole and $2 H$-1,2,3-triazole.

*e-mail: j.wardell@abdn.ac.uk<smiles>c1c[nH]nn1</smiles>

(a)<smiles>c1cn[nH]n1</smiles>

(b)
Figure 1. (a) 1H-1,2,3-triazole; (b) 2H-1,2,3-triazole.

The crystal structures of four of the moderately active hydrazonyl derivatives in the glycosidase inhibition study ${ }^{24}$ have been determined, namely of (Z)-1-phenyl-4-[((2phenylhydrazono)methyl)]-1H-1,2,3-triazole (1a), (Z)4-[(2-(2,4-dimethylphenyl)hydrazono)methyl]-2-phenyl2H-1,2,3-triazole (2a), (E)-4-[(2-(2,4-dinitrophenyl) hydrazono)methyl]-2-phenyl-2H-1,2,3-triazole (2b), 
<smiles>O=Cc1cn(-c2ccccc2)nn1</smiles>

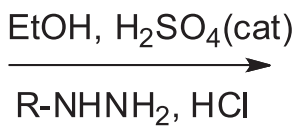<smiles>O=Cc1cnn(-c2ccccc2)n1</smiles>

Scheme 1. Preparation of compounds.

and $(E)-N$-((2-phenyl-2H-1,2,3-triazol-4-yl)methylene) isonicotinohydrazide dihydrate, $\left(3 \cdot 2 \mathrm{H}_{2} \mathrm{O}\right)$, see Scheme 1 .

An antifungal activity study of related $1 \mathrm{H}-1,2,3$ triazolyl hydrazones was also published very recently. ${ }^{13}$ The crystal structure of one of the compounds, $(E)-4-[2-$ $\left.\mathrm{ClC}_{6} \mathrm{H}_{4}-\mathrm{NH}-\mathrm{N}=\mathrm{CH}\right)-1-\left(2-\mathrm{ClC}_{6} \mathrm{H}_{4}\right)-1 H$-1,2,3-triazole $(\mathbf{1 b})$, was reported and has been deposited in the Cambridge Crystallographic Data Centre (CCDC No. 976935; ref code: FONZAL), but only the molecular configuration had been reported in the article. ${ }^{13}$ In this article, we report the crystal structures of $\mathbf{1 a}, \mathbf{2 a}, \mathbf{2} \mathbf{b}$ and $\left(\mathbf{3} 2 \mathrm{H}_{2} \mathrm{O}\right)$, and make comparisons with that of $\mathbf{1 b}$.

\section{Experimental}

\section{X-Ray crystallography}

Data for compounds $\mathbf{1 a}, \mathbf{2} \mathbf{a}$ and $\left(\mathbf{3} 2 \mathrm{H}_{2} \mathrm{O}\right)$ were obtained at $100(2) \mathrm{K}$, while data for compound $\mathbf{2 b}$ were collected at $120(2) \mathrm{K}$. All with Mo K $\alpha$ radiation by means of a Rigaku Saturn 724+ $(2 \times 2$ bin mode $)$ instrument of the National Crystallography Service (NCS), University of Southampton. Data collection, data reduction and unit cell refinement were achieved with the $\mathrm{DENZO}^{25}$ and COLLECT $^{26}$ programs. Correction for absorption was achieved in each case by a semi-empirical method based upon the variation of equivalent reflections with the Rigaku version of the program SADABS 2007/2. ${ }^{27}$ The program, MERCURY ${ }^{28}$ was used in the preparation of the Figures. SHELXL97 ${ }^{29}$ and PLATON ${ }^{30}$ were used in the calculation of molecular geometry. The structures were solved by

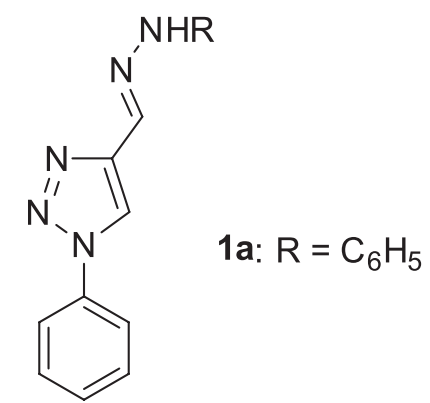<smiles></smiles>

2a: $\mathrm{R}=2,5-\mathrm{Me}_{2} \mathrm{C}_{6} \mathrm{H}_{3}$

2b: $\mathrm{R}=2,4-\left(\mathrm{O}_{2} \mathrm{~N}\right)_{2} \mathrm{C}_{6} \mathrm{H}_{3}$

3: $\mathrm{R}=4$-pyridinyl- $\mathrm{CO}$ direct methods by SHELXT and fully refined by means of the SHELXL using OSCAIL. ${ }^{31}$ Difference map provided position for the $\mathrm{N}-\mathrm{H}$ hydrogen atoms in all four compounds and for the water hydrogen atoms in $\left(32 \mathrm{H}_{2} \mathrm{O}\right)$. All other hydrogen atoms were placed in calculated positions. Crystal data and structure refinement details are listed in Table 1.

\section{Results and Discussion}

The compounds were prepared as previously reported ${ }^{24}$ from the corresponding aldehydes, see Scheme 1. Samples used in the structure determinations were grown by slow evaporation of solutions in methanol for $\mathbf{1 a}$ and $\mathbf{2 a}$, in 2-methoxyethanol for $\mathbf{2} \mathbf{b}$, and in ethyl acetate for $\mathbf{3}$. The cell dimensions for a sample of $\mathbf{2} \mathbf{b}$, recrystallized from methanol, indicated the same phase as obtained from 2-methoxyethanol. The crystals obtained from recystallisation of $\mathbf{3}$ from ethyl acetate were of the dihydrate $\left(3 \cdot 2 \mathrm{H}_{2} \mathrm{O}\right)$.

\section{Molecular conformations}

The asymmetric unit in each of $\mathbf{1 a}, \mathbf{2} \mathbf{a}$ and $\mathbf{2} \mathbf{b}$ consists of a single molecule, that of $\left(3 \cdot 2 \mathrm{H}_{2} \mathrm{O}\right)$ a molecule of $\mathbf{3}$ and two molecules of water. Figure 2 illustrates the numbering schemes for all the molecules. Selected bond lengths and angles are listed in Table 2. Comparison of the bond lengths in the triazolyl rings in the $1 H$-1,2,3-triazole, compound $\mathbf{1 a}$, and the $2 \mathrm{H}$-1,2-3-triazole compounds, $\mathbf{2 a}, \mathbf{2 b}$ and $\left(\mathbf{3} \cdot 2 \mathrm{H}_{2} \mathrm{O}\right)$, indicate that the major differences are found in the C4-C5 and C5-N1 bond lengths. The bond lengths in the 
Table 1. Crystal data and structure refinement

\begin{tabular}{|c|c|c|c|c|}
\hline & $1 \mathbf{a}$ & $\mathbf{2 a}$ & $2 \mathbf{b}$ & $\left(3.2 \mathrm{H}_{2} \mathrm{O}\right)$ \\
\hline Empirical formula & $\mathrm{C}_{15} \mathrm{H}_{13} \mathrm{~N}_{5}$ & $\mathrm{C}_{17} \mathrm{H}_{17} \mathrm{~N}_{5}$ & $\mathrm{C}_{15} \mathrm{H}_{11} \mathrm{~N}_{7} \mathrm{O}_{4}$ & $\mathrm{C}_{15} \mathrm{H}_{16} \mathrm{~N}_{6} \mathrm{O}_{3}$ \\
\hline Formula weight & 263.30 & 291.38 & 353.31 & 328.34 \\
\hline Temperature / K & $100(2)$ & $100(2)$ & $120(2)$ & $100(2)$ \\
\hline Crystal system, space group & triclinic, $P-1$ & monoclinic, $P 2_{1} / \mathrm{n}$ & triclinic, $P-1$ & monoclinic, $P 2_{1} / \mathrm{c}$ \\
\hline \multicolumn{5}{|l|}{ Unit cell dimensions } \\
\hline$a / \AA$ & $5.7096(4)$ & $15.139(7)$ & $9.2315(3)$ & $9.2332(6)$ \\
\hline$b / \AA$ & $7.2055(5)$ & $5.5315(17)$ & $9.5903(5)$ & $11.9186(7)$ \\
\hline$c / \AA$ & $15.7986(11)$ & $17.352(8)$ & $9.6938(6)$ & $14.0316(9)$ \\
\hline$\alpha /$ degree & $98.715(10$ & 90 & $89.796(6)$ & 90 \\
\hline$\beta /$ degree & $99.437(10)$ & $94.300(4)$ & $65.000(8)$ & $95.041(7)$ \\
\hline$\gamma /$ degree & $90.9490(10)$ & 90 & $85.248(7)$ & 90 \\
\hline Volume / $\AA^{3}$ & $633.19(8)$ & $1448.9(10)$ & $774.67(7)$ & $1538.16(17)$ \\
\hline $\mathrm{Z}$ & 2 & 4 & 2 & 4 \\
\hline Density (calculated) / $\left(\mathrm{mg} \mathrm{m}^{-3}\right)$ & 1.381 & 1.336 & 1.515 & 1.418 \\
\hline Absorption coefficient $/ \mathrm{mm}^{-1}$ & 0.088 & 0.084 & 0.115 & 0.103 \\
\hline $\mathrm{F}(000)$ & 276 & 616 & 364 & 688 \\
\hline Crystal size / mm & $0.11 \times 0.07 \times 0.03$ & $0.24 \times 0.04 \times 0.04$ & $0.96 \times 0.53 \times 0.23$ & $0.16 \times 0.096 \times 0.06$ \\
\hline$\theta$ range for data collection / degree & 2.65 to 27.48 & 3.45 to 27.62 & 3.10 to 27.43 & 3.06 to 27.48 \\
\hline Index ranges & $\begin{array}{c}-6 \leq \mathrm{h} \leq 7 \\
-9 \leq \mathrm{k} \leq 9 \\
-20 \leq 1 \leq 20\end{array}$ & $\begin{array}{c}-16 \leq \mathrm{h} \leq 19 \\
-7 \leq \mathrm{k} \leq 4 \\
-22 \leq 1 \leq 21\end{array}$ & $\begin{array}{l}-11 \leq \mathrm{h} \leq 11 \\
-12 \leq \mathrm{k} \leq 12 \\
-12 \leq 1 \leq 12\end{array}$ & $\begin{array}{l}-8 \leq \mathrm{h} \leq 11 \\
-15 \leq \mathrm{k} \leq 11 \\
-18 \leq 1 \leq 18\end{array}$ \\
\hline Reflections collected & 7812 & 8351 & 9903 & 9099 \\
\hline Independent reflections & $\begin{array}{c}2856 \\
\left(R_{\mathrm{int}}=0.0398\right)\end{array}$ & $\begin{array}{c}3306 \\
\left(R_{\text {int }}=0.0218\right)\end{array}$ & $\begin{array}{c}3511 \\
\left(\mathrm{R}_{\mathrm{int}}=0.0205\right)\end{array}$ & $\begin{array}{c}3511 \\
\left(\mathrm{R}_{\mathrm{int}}=0.0438\right)\end{array}$ \\
\hline Reflections observed ( $>$ 2sigma) & 1959 & 2891 & 2982 & 2481 \\
\hline Data completeness & 0.98 & 0.98 & 1.00 & 1.00 \\
\hline Data/restraints/parameters & $2856 / 0 / 184$ & $3306 / 0$ / 204 & $3511 / 0 / 238$ & $3511 / 0 / 232$ \\
\hline Goodness-of-fit on $\mathrm{F}^{2}$ & 0.89 & 1.06 & 1.10 & 1.02 \\
\hline Final $R$ indices $[I>2 \operatorname{sigma}(I)]$ & $\begin{array}{c}\mathrm{R}_{1}=0.042 \\
\mathrm{wR}^{2}=0.102\end{array}$ & $\begin{array}{c}\mathrm{R}_{1}=0.053 \\
\mathrm{wR}_{2}=0.116\end{array}$ & $\begin{array}{c}\mathrm{R}_{1}=0.035 \\
\mathrm{wR}_{2}=0.097\end{array}$ & $\begin{array}{c}\mathrm{R}_{1}=0.043 \\
\mathrm{wR}_{2}=0.101\end{array}$ \\
\hline $\mathrm{R}$ indices (all data) & $\begin{array}{c}\mathrm{R}_{1}=0.071 \\
\mathrm{wR}_{2}=0.114\end{array}$ & $\begin{array}{c}\mathrm{R}_{1}=0.062 \\
\mathrm{wR}_{2}=0.122\end{array}$ & $\begin{array}{c}\mathrm{R}_{1}=0.041 \\
\mathrm{wR}_{2}=0.105\end{array}$ & $\begin{array}{c}\mathrm{R}_{1}=0.066 \\
\mathrm{wR}_{2}=0.108\end{array}$ \\
\hline Largest diff. peak and hole / $\left(\mathrm{e} \AA^{-3}\right)$ & 0.26 and -0.28 & 0.21 and -0.22 & 0.24 and -0.23 & 0.26 and -0.27 \\
\hline CCDC No. & 1434781 & 1434786 & 1434776 & 1434783 \\
\hline
\end{tabular}

hydrazonyl linker, C13-N5-N4-C6-C4, in compounds 1a, $\mathbf{1 b}$ and 2a, indicate that electron delocalization occurs within the link, as do the bond lengths in the acylhydrazonyl linker, C14-C13(O1)-N5-N4-C6-C4, in molecule 3.

The most significant conformational result is that compounds 1a and 2a have $(Z)$ geometries about the $\mathrm{C}=\mathrm{N}$ bond, in contrast to the $(E)$-configuration in $\mathbf{2 b}$ and $\left(\mathbf{3} \cdot 2 \mathrm{H}_{2} \mathrm{O}\right)$ (Figure 2); compound $\mathbf{1} \mathbf{b}^{13}$ also has the (E)-configuration (Figure 3a). Generally in the absence of special circumstances, $(Z)$-isomers are thermodynamically less stable than $(E)$-isomers. The special circumstances in 1a and 2a must be the formations of the classical and strong N5-HN5 $\cdots \mathrm{N} 3$ intramolecular hydrogen bonds, which enhance the stability of the (Z)-isomers. On the other hand, the $(E)$-configuration in the 2,4-dinitrophenyl derivative, $\mathbf{2 b}$ does permit the formation of strong classical N4-HN5 ‥O1 intermolecular hydrogen bonds, involving an oxygen atom of the ortho-nitro group. Such a strong N4-HN5 ‥O1 intermolecular hydrogen bond in $\mathbf{2 b}$ must further enhance the stability of the $(E)$-configuration of $\mathbf{1 b}$ over that of the (Z)-isomer. For compound $\mathbf{1 b}$, it is argued that the ortho-chloro substituent prevents the formation of a (Z)-configuration, due to the potential steric hindrance between chlorine and adjacent atoms (see Figure $3 b$ ). In Figure $3 b$ are drawn the two possibilities for (Z)-(1b), arising from the two possible positions of the chloro group in the phenyl ring. The chlorine atom would be uncomfortably close in (i) to the $\mathrm{N}-\mathrm{H}$ bond and in (ii) to a nitrogen atom.

The arrangement about the $\mathrm{C}(\mathrm{O})-\mathrm{NH}-\mathrm{N}=\mathrm{CH}$-aryl fragment in $\mathbf{3}$ is designated as $E_{C(O) N H} / E_{C=N}$. As reported for many acylhydrazones, such as $\mathbf{3}$, there are two potential configurations about the $\mathrm{C}(\mathrm{O})-\mathrm{NH}$ bond $\left(E_{C(O) N H}\right.$ and $\left.Z_{\mathrm{C}(O) N H}\right)$, as well as the two geometric isomers about the $\mathrm{C}=\mathrm{N}$ 
(a)

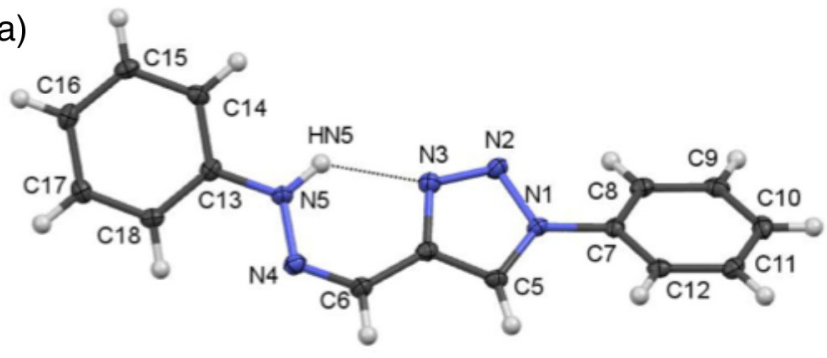

(c)

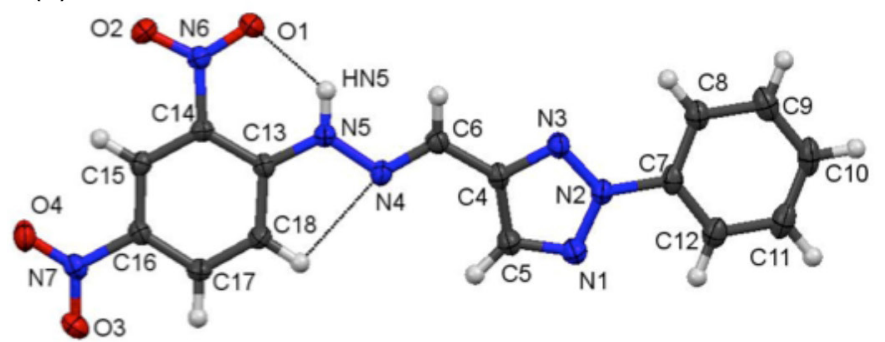

(b)

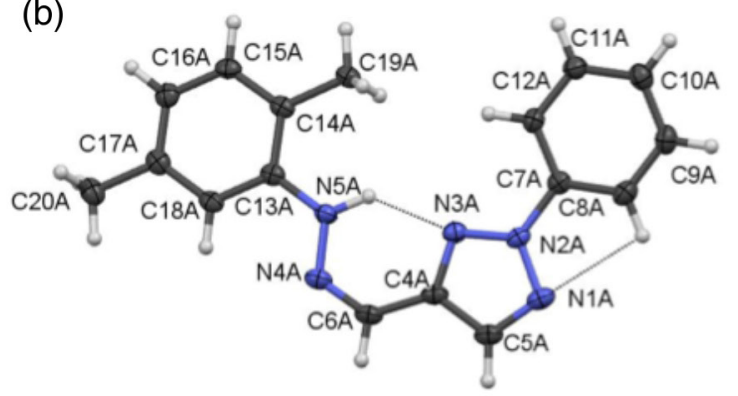

(d)

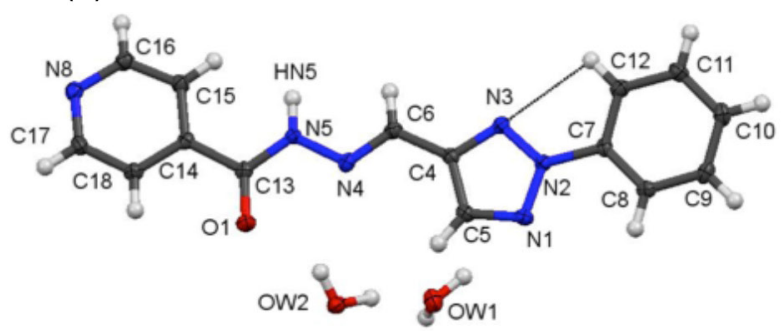

Figure 2. Atom arrangements and numbering schemes for (a) $\mathbf{1 a}$, (b) $\mathbf{2 a}$, (c) $\mathbf{2} \mathbf{b}$, and (d) $\left(\mathbf{3} 2 \mathrm{H}_{2} \mathrm{O}\right)$. Ellipsoids are drawn at the $50 \%$ level. Hydrogen atoms are drawn as spheres of arbitrary radius. Intramolecular hydrogen bonds are drawn as thin dashed lines.

Table 2. Selected bond lengths (§) and angles (degree)

\begin{tabular}{|c|c|c|c|c|}
\hline & $1 \mathbf{a}$ & $2 \mathbf{a}$ & $2 \mathbf{b}$ & $\left(3.2 \mathrm{H}_{2} \mathrm{O}\right)$ \\
\hline C13-N5 & $1.4005(18)$ & $1.395(2)$ & $1.3524(14)$ & $1.3519(13)$ \\
\hline $\mathrm{N} 5-\mathrm{N} 4$ & $1.3626(18)$ & $1.3502(18)$ & $1.3757(13)$ & $1.3772(15)$ \\
\hline $\mathrm{N} 4-\mathrm{C} 6$ & $1.2940(19)$ & $1.295(3)$ & $1.2812(14)$ & $1.2769(18)$ \\
\hline $\mathrm{C} 6-\mathrm{C} 4$ & $1.455(2)$ & $1.446(3)$ & $1.4551(15)$ & $1.4494(18)$ \\
\hline $\mathrm{C} 4-\mathrm{C} 5$ & $1.377(2)$ & $1.403(3)$ & $1.4031(16)$ & $1.397(2)$ \\
\hline $\mathrm{C} 5-\mathrm{N} 1$ & $1.3466(19)$ & $1.323(3)$ & $1.3245(16)$ & $1.3245(16)$ \\
\hline $\mathrm{N} 1-\mathrm{N} 2$ & $1.3600(17)$ & $1.3452(17)$ & $1.3449(13)$ & $1.3429(16)$ \\
\hline $\mathrm{N} 2-\mathrm{N} 3$ & $1.3155(17)$ & $1.339(2)$ & $1.3550(13)$ & $1.3318(15)$ \\
\hline $\mathrm{N} 3-\mathrm{C} 4$ & $1.375(2)$ & $1.346(2)$ & $1.3384(14)$ & $1.3342(18)$ \\
\hline C13-N5-N4 & $118.14(12)$ & $119.79(14)$ & 118.97(9) & $117.58(12)$ \\
\hline N5-N4-C6 & $118.39(15)$ & $118.44(15)$ & $115.19(10)$ & $116.68(12)$ \\
\hline N4-C6-C4 & $129.14(15)$ & $129.27(15)$ & $118.73(10)$ & $118.03(13)$ \\
\hline C18-C13-N5-N4 & $21.9(2)$ & $1.3(2)$ & $8.82(17)$ & \\
\hline $\mathrm{C} 15-\mathrm{C} 14-\mathrm{C} 13-\mathrm{N} 5$ & & & & $8.2(2)$ \\
\hline C18-C14-C13-N5 & & & & $173.02(13)$ \\
\hline C15-C14-C13-O1 & & & & $171.29(13)$ \\
\hline C18-C14-C13-O1 & & & & $7.5(2)$ \\
\hline C14-C13-N5-N4 & $159.39(14)$ & $179.36(15)$ & $172.05(11)$ & 179.94(11) \\
\hline C13-N5-N4-C6 & $177.85(13)$ & 179.16(16) & $177.03(11)$ & $175.48(13)$ \\
\hline $\mathrm{N} 5-\mathrm{N} 4-\mathrm{C} 6-\mathrm{C} 4$ & $1.4(2)$ & $0.2(3)$ & $176.56(11)$ & $179.05(12)$ \\
\hline N4-C6-C4-N3 & $1.8(3)$ & $2.4(3)$ & $179.51(12)$ & $176.87(13)$ \\
\hline N4-C6-C4-C5 & $178.51(15)$ & $176.1(2)$ & $0.7(2)$ & $1.1(2)$ \\
\hline
\end{tabular}

bond $\left(E_{C=N}\right.$ and $\left.Z_{C=N}\right)$, making four possible arrangements in all about the $\mathrm{C}(\mathrm{O})-\mathrm{NH}-\mathrm{N}=\mathrm{CH}$-aryl fragment. ${ }^{32-35}$

While the triazolyl ring is planar in all compounds, none of the compounds is planar overall. The deviation from planarity is relatively small for the $2 \mathrm{H}$-1,2,3-triazolyl compounds, $\mathbf{2} \mathbf{a}, \mathbf{2} \mathbf{b}$ and $\mathbf{3}$, as shown by the angles between the aryl rings in Table 3, and very much larger for $\mathbf{1 a}$ and 1b (see Figure 4). The increased deviation from planarity of the triazole and its attached phenyl ring in a $\mathrm{H}-1,2,3-$ triazolyl may arise from steric repulsions between the ortho $\mathrm{C}-\mathrm{H}$ bonds in the triazole ring and the phenyl ring. Of interest, the sums of the dihedral angles between the 


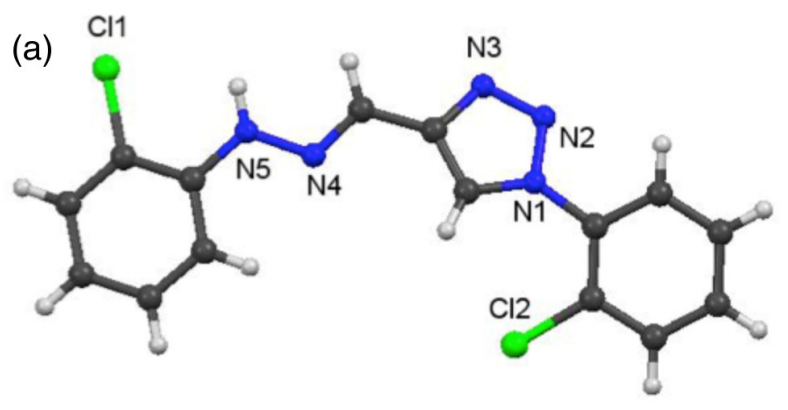

(b)<smiles>[Al]n1cc(C=NNc2ccccc2Cl)nn1</smiles>

Figure 3. (a) The (E)-geometric form determined for $\mathbf{1 b}$ in the solid state; ${ }^{13}$ (b) potential $(Z)$-forms of $\mathbf{1 b}$. $\mathrm{Ar}=2$-chlorophenyl.

phenyl groups and the triazolyl ring are very similar to the single dihedral angle between the two phenyl rings in each of $1 \mathbf{a}, \mathbf{2 a}, \mathbf{2 b}$ and $\mathbf{3}$, which indicates that the deviation from planarity can be considered to have arisen from rotations about the C13-N5 and C7-N2 bonds occurring in the same sense. This is not the case in the $1 H-1,2,3$-triazolyl compound, $\mathbf{1 b}$. For $\mathbf{1 b}$, the dihedral angles point to rotations about the C13-N5 and C7-N2 bonds occurring in the opposite senses, with the result that the two phenyl groups have a small dihedral angle of ca. $6^{\circ}$, compared to ca. $51^{\circ}$ in 1a. If rotations about these C13-N5 and C7-N2 bonds did occur in the same sense, it would place either $\mathrm{Cl1}$ too close to $\mathrm{N} 5$, or $\mathrm{Cl} 2$ too close to $\mathrm{N} 2$.

Dihedral angles between aryl and triazolyl rings in 1-aryl- $1 H$ - and 2-aryl- $2 H$-1,2,3-triazole compounds have been shown to vary considerably, for example, such angles are $0.34(17)$ and $87.1(2)^{\circ}$, respectively, in 4-(difluoromethyl)- $1 \mathrm{H}$-1,2,3-triazole, ${ }^{36}$ and in one independent molecule of 1-[5-methyl-1-(4-nitrophenyl) methyl-1-(4-methylphenyl)-1H-1,2,3-triazol-4-yl] ethanone. ${ }^{37}$ The aryl group substituents and crystal packing effects have major influences on such dihedral angles. The
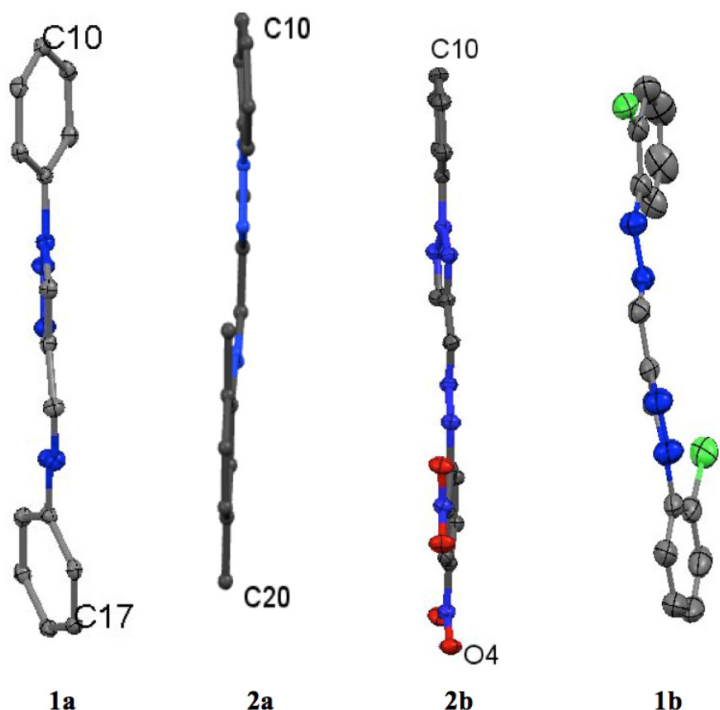

Figure 4. Molecular conformations. Hydrogen atoms have been omitted.

dihedral angles in $\mathbf{2 a}$ between the phenyl group and (i) the attached ortho-nitro group, O2-N6-O1, and (ii) para-nitro group, O3-N7-O4, are 3.93 and $13.69^{\circ}$, respectively. The small angle between the phenyl and its ortho-nitro group facilitates the formation of the N5-HN5 ...O1 intramolecular hydrogen bond.

\section{Crystal structures}

\section{Compound 1a}

The only classical hydrogen bond present in $\mathbf{1 a}$ is the

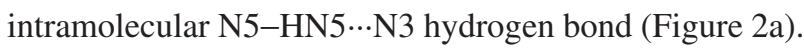
The intermolecular interactions in $\mathbf{1 a}$ are four $\mathrm{C}-\mathrm{H} \cdots \pi$ interactions (Table 4). ${ }^{38}$

The combination of the $\mathrm{C}-\mathrm{H} \cdots \pi$ interactions, $\mathrm{C} 9-\mathrm{H} 9 \cdots \pi$ (phenyl- $b$ ), C12-H $12 \cdots \pi$ (phenyl- $b$ ), $\mathrm{C} 15-\mathrm{H} 15 \cdots \pi$ (phenyl- $a$ ) and $\mathrm{C} 18-\mathrm{H} 18 \cdots \pi$ (phenyl- $a$ ), provides sheets of molecules in the $a b$ plane, as shown in Figure 5. Phenyl- $a$ and phenyl- $b$ are the phenyl groups with atoms $\mathrm{C} 7-\mathrm{C} 12$ and $\mathrm{C} 13-\mathrm{C} 18$, respectively. The triazole ring is not involved in $\mathrm{C}-\mathrm{H} \cdots \pi$ interactions. The PLATON analysis ${ }^{31}$ indicates the possibility of $\pi($ triazolyl $) \cdots \pi\left(\right.$ triazolyl) stacking interactions.${ }^{39}$ However,

Table 3. Angles between the best planes through the aryl rings

\begin{tabular}{lccc}
\hline Compound & $\begin{array}{c}\text { Angle between free phenyl and } \\
\text { triazole / degree }\end{array}$ & $\begin{array}{c}\text { Angle between free phenyl and } \\
\text { phenyl on triazole / degree }\end{array}$ & $\begin{array}{c}\text { Angle between triazole and } \\
\text { attached phenyl / degree }\end{array}$ \\
\hline 1a & $23.72(8)$ & $51.15(7)$ & $28.54(8)$ \\
2a & $2.58(9)$ & $7.13(8)$ & $4.64(9)$ \\
2b & $14.06(7)$ & $8.66(6)$ & $6.92(7)$ \\
$\left(32 \mathrm{H}_{2} \mathrm{O}\right)$ & $6.35(7)$ & $11.19(7)$ & $5.28(7)$ \\
$\mathbf{1} \mathbf{b}^{13}$ & $23.34(8)$ & $6.57(8)$ & $27.67(8)$ \\
\hline
\end{tabular}


Table 4. Geometric parameters ( $\AA$, degree) for intra- and intermolecular interactions

\begin{tabular}{|c|c|c|c|c|c|}
\hline \multicolumn{6}{|c|}{ Intramolecular hydrogen bonds } \\
\hline Compound & $\mathrm{D}-\mathrm{H} \cdots \mathrm{A}$ & $\mathrm{D}-\mathrm{H}$ & $\mathrm{H} \cdots \mathrm{A}$ & $\mathrm{D} \cdots \mathrm{A}$ & $\mathrm{D}-\mathrm{H} \cdots \mathrm{A}$ \\
\hline$\overline{1 a}$ & N5-HN5 $\cdots$ N3 & $0.949(17)$ & $2.067(17)$ & $2.7829(18)$ & $131.0(14)$ \\
\hline $2 a$ & N5-HN5 $\cdots \mathrm{N} 3$ & $0.929(17)$ & $2.042(17)$ & $2.768(2)$ & $133.9(15)$ \\
\hline $2 a$ & $\mathrm{C} 8 \mathrm{H} 8 \cdots \mathrm{N} 1$ & 0.95 & 2.49 & $2.808(3)$ & 100 \\
\hline $2 \mathbf{b}$ & N5-HN5 $\cdots \mathrm{O} 1$ & $0.898(14)$ & $1.975(14)$ & $2.6342(14)$ & $129.1(14)$ \\
\hline $2 \mathbf{b}$ & 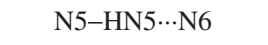 & $0.898(14)$ & $2.621(16)$ & $2.9512(15)$ & $102.7(11)$ \\
\hline $2 \mathbf{b}$ & $\mathrm{C} 18-\mathrm{H} 18 \cdots \mathrm{N} 4$ & 0.95 & 2.40 & $2.7320(16)$ & 100 \\
\hline$\left(3 \cdot 2 \mathrm{H}_{2} \mathrm{O}\right)$ & $\mathrm{C} 12-\mathrm{H} 12 \cdots \mathrm{N} 3$ & 0.93 & 2.50 & $2.8069(18)$ & 100 \\
\hline \multicolumn{6}{|c|}{ Intermolecular hydrogen bonds } \\
\hline Compound & $\mathrm{D}-\mathrm{H} \cdots \mathrm{A}$ & $\mathrm{D}-\mathrm{H}$ & $\mathrm{H} \cdots \mathrm{A}$ & $\mathrm{D} \cdots \mathrm{A}$ & $\mathrm{D}-\mathrm{H} \cdots \mathrm{A}$ \\
\hline$\overline{2 b}$ & N5-HN5 $\cdots \mathrm{O}^{i}$ & $0.898(14)$ & $2.520(15)$ & $3.3218(14)$ & $149.0(14)$ \\
\hline $2 \mathbf{b}$ & $\mathrm{C} 5-\mathrm{H} 5 \cdots \mathrm{O} 3^{i i}$ & 0.95 & 2.53 & $3.3984(18)$ & 152 \\
\hline $2 \mathbf{b}$ & C6-H6 $\cdots 3^{i i i}$ & 0.95 & 2.60 & $3.0389(15)$ & 109 \\
\hline $2 \mathbf{b}$ & $\mathrm{C} 6-\mathrm{H} 6 \cdots \mathrm{O} 2^{i}$ & 0.95 & 2.60 & $3.5082(15)$ & 160 \\
\hline $2 b$ & $\mathrm{C} 11-\mathrm{H} 11 \cdots \mathrm{O} 4^{i v}$ & 0.95 & 2.52 & $3.2179(18)$ & 130 \\
\hline$\left(3 \cdot 2 \mathrm{H}_{2} \mathrm{O}\right)$ & OW2-HW1A ‥O1 & $0.836(18)$ & $2.072(18)$ & $2.8281(150$ & $150.2(17)$ \\
\hline$\left(3 \cdot 2 \mathrm{H}_{2} \mathrm{O}\right)$ & OW2-HW1A ‥N4 & $0.836(18)$ & $2.562(19)$ & $3.2512(16)$ & $140.6(15)$ \\
\hline$\left(3 \cdot 2 \mathrm{H}_{2} \mathrm{O}\right)$ & OW2-HW1B ‥OW1 & $0.959(18)$ & $1.773(18)$ & $2.7198(16)$ & $168.5(16)$ \\
\hline$\left(3 \cdot 2 \mathrm{H}_{2} \mathrm{O}\right)$ & 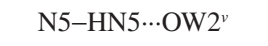 & $0.869(18)$ & $2.048(18)$ & $2.8974(17)$ & $165.6(14)$ \\
\hline$\left(3 \cdot 2 \mathrm{H}_{2} \mathrm{O}\right)$ & OW1-HW2A $\cdots$ OW2 $2^{v i}$ & $0.787(18)$ & $2.119(18)$ & $2.8742(16)$ & $161.0(18)$ \\
\hline$\left(3 \cdot 2 \mathrm{H}_{2} \mathrm{O}\right)$ & OW1-HW2B $\cdots \mathrm{N} 8^{v i i}$ & $0.886(18)$ & 1.975917) & $2.8457(17)$ & $167.2(16)$ \\
\hline$\left(3 \cdot 2 \mathrm{H}_{2} \mathrm{O}\right)$ & C6-H6 $\cdots$ OW $2^{v}$ & 0.93 & 2.55 & $3.3076(18)$ & 138 \\
\hline$\left(3 \cdot 2 \mathrm{H}_{2} \mathrm{O}\right)$ & $\mathrm{C} 9-\mathrm{H} 9 \cdots \mathrm{OW} 1^{\text {viii }}$ & 0.93 & 2.56 & $3.4728(19)$ & 169 \\
\hline$\left(3 \cdot 2 \mathrm{H}_{2} \mathrm{O}\right)$ & $\mathrm{C} 15-\mathrm{H} 15 \cdots \mathrm{OW} 2^{v}$ & 0.93 & 2.52 & $3.3985(18)$ & 158 \\
\hline
\end{tabular}

Symmetry codes: $i=1-\mathrm{x}, 1-\mathrm{y},-1-\mathrm{z} ; i i=1-\mathrm{x}, 2-\mathrm{y},-\mathrm{z} ; i i i=\mathrm{x}, \mathrm{y},-1+\mathrm{z} ; i v=-1+\mathrm{x}, 1+\mathrm{y},-1+\mathrm{z} ; v=-\mathrm{x},-1 / 2+\mathrm{y}, 1 / 2+\mathrm{z} ; v i=-\mathrm{x}, 1-\mathrm{y}, 1-\mathrm{x}$; vii $=1+\mathrm{x}, 1 / 2-\mathrm{y}, 1 / 2+\mathrm{z} ;$ viii $=1-\mathrm{x}, \mathrm{y}, \mathrm{z}$.

\begin{tabular}{|c|c|c|c|c|c|c|c|}
\hline \multicolumn{8}{|c|}{$\mathrm{Y}-\mathrm{X} \cdots \pi$ interactions $^{\mathrm{a}}$} \\
\hline$\underline{\text { Compound }}$ & $\mathrm{Y}-\mathrm{X} \cdots \mathrm{Cg}^{\mathrm{a}}$ & $\mathrm{X} \cdots \mathrm{Cg}$ & $X_{\text {perp }}$ & $\gamma$ & $\mathrm{Y}-\mathrm{X} \cdots \mathrm{Cg}$ & $\mathrm{Y} \cdots \mathrm{Cg}$ & \\
\hline $1 \mathbf{a}$ & $\mathrm{C} 9-\mathrm{H} 9 \cdots \mathrm{Cg} 3^{i}$ & 2.68 & 2.67 & 5.81 & 131 & $3.3796(17)$ & \\
\hline 1a & $\mathrm{C} 12-\mathrm{H} 12 \cdots \mathrm{Cg} 3^{i i}$ & 2.63 & 2.62 & 6.29 & 131 & $3.3403(16)$ & \\
\hline 1a & $\mathrm{C} 15-\mathrm{H} 15 \cdots \mathrm{Cg} 2^{i i i}$ & 2.78 & 2.75 & 8.72 & 131 & $3.4822(17)$ & \\
\hline 1a & $\mathrm{C} 18-\mathrm{H} 18 \cdots \mathrm{Cg} 2^{i v}$ & 2.76 & 2.72 & 10.36 & 129 & $3.4370(16)$ & \\
\hline $2 \mathbf{a}$ & $\mathrm{C} 19-\mathrm{H} 19 \mathrm{~B} \cdots \mathrm{Cg} 2^{v}$ & 2.81 & 2.68 & 17.59 & 150 & $3.692(2)$ & \\
\hline $2 \mathbf{b}$ & $\mathrm{N} 7-\mathrm{O} 4 \cdots \mathrm{Cg} 2^{v i}$ & $3.7402(11)$ & 3.37 & 25.73 & $74.54(6)$ & $3.6125(12)$ & \\
\hline \multicolumn{8}{|c|}{ Symmetry codes: $i=-\mathrm{x}, 1-\mathrm{y}, 1-\mathrm{z} ; i i=1-\mathrm{x}, 2-\mathrm{y}, 1-\mathrm{z} ; i i i=-\mathrm{x}, 2-\mathrm{y}, 1-\mathrm{x} ; i v=1-\mathrm{x}, 1-\mathrm{y}, 1-\mathrm{z} ; v=\mathrm{x}, 1+\mathrm{y}, \mathrm{z} ; v i=1-\mathrm{x}, 2-\mathrm{y},-1-\mathrm{z}$} \\
\hline \multicolumn{8}{|c|}{$\pi \cdots \pi$ interactions $^{\mathrm{a}}$} \\
\hline Compound & $\mathrm{Cg}(\mathrm{I}) \cdots \mathrm{Cg}(\mathrm{J})$ & $\mathrm{Cg} \cdots \mathrm{Cg}$ & $\alpha$ & $\beta$ & $\gamma$ & $\mathrm{CgI}_{\text {perp }}$ & $\mathrm{CgJ}_{\text {perp }}$ \\
\hline $1 \mathrm{a}$ & $\mathrm{Cg} 1 \cdots \mathrm{Cg} 1^{i}$ & $4.2304(9)$ & 0.02 & 34.8 & 34.8 & 3.48 & 3.475 \\
\hline $2 a$ & $\mathrm{Cg} 1 \cdots \mathrm{Cg} 2^{i i}$ & $3.726(2)$ & $4.58(9)$ & 27.4 & 22.8 & $3.4350(7)$ & $3.3089(6)$ \\
\hline $2 a$ & $\mathrm{Cg} 2 \cdots \mathrm{Cg} 1^{i i}$ & $3.726(2)$ & $4.58(9)$ & 22.8 & 27.4 & $3.3089(6)$ & $3.4350(7)$ \\
\hline $2 a$ & $\mathrm{Cg} 3 \cdots \operatorname{Cg} 1^{i i i}$ & $4.065(2)$ & 2.64(9) & 33.3 & 30.7 & 3.493597) & $3.3986(7)$ \\
\hline $2 b$ & $\mathrm{Cg} 1 \cdots \mathrm{Cg} 1^{i v}$ & $3.8953(8)$ & 0.03 & 32.4 & 32.4 & 3.27 & 3.265 \\
\hline $2 \mathbf{b}$ & $\mathrm{Cg} 2 \cdots \mathrm{Cg} 3^{v}$ & $4.0523(9)$ & 8.66 & 30.4 & 36.7 & 3.25 & 3.294 \\
\hline $2 b$ & $\mathrm{Cg} 3 \cdots \mathrm{Cg} 1^{v}$ & $3.8968(7)$ & 14.05 & 26.6 & 26.2 & 3.50 & 3.484 \\
\hline$\left(3 \cdot 2 \mathrm{H}_{2} \mathrm{O}\right)$ & $\mathrm{Cg} 1 \cdots \mathrm{Cg} 2^{v i}$ & $3.5089(8)$ & 5.28 & 12.6 & 7.5 & 3.48 & 3.425 \\
\hline$\left(3 \cdot 2 \mathrm{H}_{2} \mathrm{O}\right)$ & $\mathrm{Cg} 1 \cdots \mathrm{Cg} 2^{v i i}$ & $3.9188(8)$ & 8.00 & 32.3 & 36.0 & 3.17 & 3.314 \\
\hline$\left(3 \cdot 2 \mathrm{H}_{2} \mathrm{O}\right)$ & $\mathrm{Cg} 3 \cdots \mathrm{Cg} 2^{v i i}$ & $3.9611(8)$ & 14.12 & 44.0 & 23.8 & 3.63 & 3.246 \\
\hline
\end{tabular}

Symmetry operation: $i=1-\mathrm{x}, 1-\mathrm{y}, 1-\mathrm{z} ; i i=1-\mathrm{x},-\mathrm{y}, 1-\mathrm{z} ; i i i=\mathrm{x}, 1+\mathrm{y}, \mathrm{z} ; i v=-\mathrm{x}, 2-\mathrm{y},-1-\mathrm{z} ; v=1-\mathrm{x}, 2-\mathrm{y},-1-\mathrm{z} ; v i=1+\mathrm{x}, \mathrm{y}, \mathrm{z} ; v i i=1+\mathrm{x}$, $1 / 2-\mathrm{y}, 1 / 2+\mathrm{z}$.

In compounds 1a and $\mathbf{2 b}, \mathrm{Cg} 1, \mathrm{Cg} 2$ and $\mathrm{Cg} 3$ are the centroids of the ring containing $\mathrm{N} 2, \mathrm{C} 10$ and $\mathrm{C} 16$, respectively; in compound $\mathbf{3}, \mathrm{Cg} 1, \mathrm{Cg} 2$ and $\mathrm{Cg} 3$ are the centroids of the ring containing N2, $\mathrm{C} 16$ and $\mathrm{C} 10$, respectively; in compound $\mathbf{2 a}, \mathrm{Cg} 1, \mathrm{Cg} 2, \mathrm{Cg} 3, \mathrm{Cg} 4, \mathrm{Cg} 5$ and $\mathrm{Cg} 6$ are the centroids of the ring containing N2A, C10A, C16A, N2B, C10B and C16B, respectively; $\beta$ is the angle between the vectors Cg... Cg and $\mathrm{CgI}_{\text {perp }}$, where $\mathrm{CgI}_{\text {perp }}$ is the perpendicular distance of $\mathrm{CgI}$ from the plane of ring J. Similarly, $\gamma$ is the angle between the vectors $\mathrm{Cg} \cdots \mathrm{Cg}$ and $\mathrm{CgJ}_{\text {perp }}$. $\mathrm{CgJ}_{\text {perp }}$ is the perpendicular distance of $\mathrm{CgI}$ from the plane of ring I. 


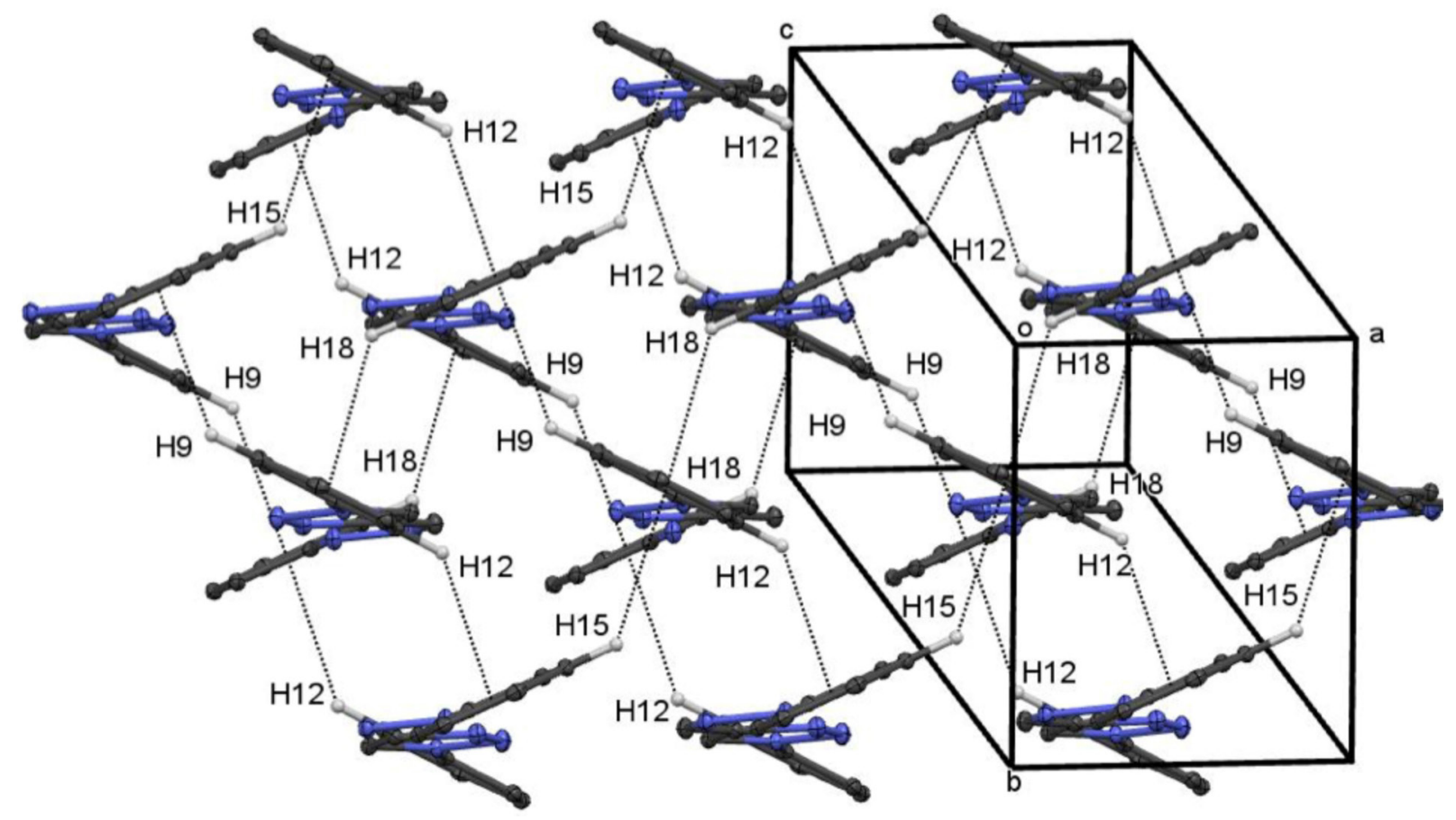

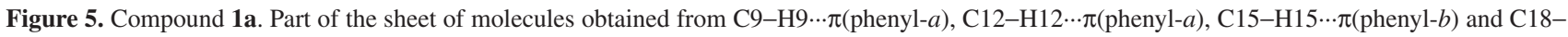
H18 $\cdots \pi($ phenyl- $b$ ) in the $a b$ plane; phenyl- $a$ and phenyl- $b$ are the free and triazole-bound phenyl, respectively.

although the perpendicular distance between parallel triazole rings is only $3.475 \AA$, the $\mathrm{Cg} \ldots \mathrm{Cg}$ distance is large at 4.2304(9) $\AA$, resulting in ring offsets of $2.413 \AA$, which indicates that the triazole rings do not overlap.

\section{Compound $\mathbf{2 a}$}

The major intermolecular interactions in $\mathbf{2} \mathbf{a}$ are $\pi \cdots \pi$ stacking interactions. Dimers are generated from pairs of $\pi$ (triazole) $\cdots \pi$ (phenyl- $a$ ) interactions. These dimeric units are further linked by $\pi$ (triazole $) \cdots \pi($ phenyl $-b)$ and by $\mathrm{C}-\mathrm{H} \cdots \pi$ (phenyl- $a$ ) interactions into two molecule wide columns, where phenyl- $a$ and phenyl- $b$ refer to the phenyl group attached to the triazole and the other phenyl group, respectively (Figure 6a). These two-molecular wide columns are free standing and so $\mathbf{2 a}$ has a onedimensional structure. As shown in Figure 6b, such columns of molecules are propagated in different directions, with angles between the best planes of ca. $76^{\circ}$.

\section{Compound $\mathbf{2 b}$}

As well as the classical intramolecular $\mathrm{N}-\mathrm{H} \cdots \mathrm{O}$ hydrogen bond, there is also a classical intermolecular $\mathrm{N}-\mathrm{H} \cdots \mathrm{O}$ hydrogen bond, and weaker intermolecular $\mathrm{C}-\mathrm{H} \cdots \mathrm{O}$ hydrogen bonds, $\pi \cdots \pi$ stacking and $\mathrm{N}-\mathrm{O} \cdots \pi$ interactions (Table 4). ${ }^{40,41}$ In the following discussion, the overall structure is broken down into three sub-structures. Firstly, pairs of the classical intermolecular N5-HN5 ‥O1 and weaker $\mathrm{C} 11-\mathrm{H} 11 \cdots \mathrm{O} 4$ hydrogen bonds form centrosymmetric dimers, as shown in Figure 7a. Included within these dimers are intramolecular N5-HN5 -.OO1 hydrogen bonds: together, these hydrogen bonds generate a set of $\mathrm{R}_{2}{ }_{2}(8), \mathrm{R}_{2}{ }_{2}(4)$ and $\mathrm{R}_{2}{ }_{2}(8)$ rings. The $\mathrm{O} 1 \cdots \mathrm{O} 1$ distance in the O1-NH5-O1-NH5 ring is short. Secondly, ladders of molecules, containing $\mathrm{R}_{2}^{2}(24)$ and $\mathrm{R}_{2}{ }_{2}(24)$ rings, ${ }^{42}$ are generated from the combination of $\mathrm{C} 5-\mathrm{H} 5 \cdots \mathrm{O} 3$ and C6-H6 ..O3 hydrogen bonds: in these ladders, the C5-H5 ‥O3 hydrogen bonds form the rings of the ladder and the C6-H6…O3 form the sides (see Figure 7b). The third sub-structure is a sheet of molecules generated from $\pi$ (triazole) $\cdots \pi$ (nitrophenyl), $\pi$ (phenyl) $\cdots \pi$ (nitrophenyl) and $\pi$ (triazole) $\cdots \pi$ (triazole) stacking interactions, N7-O4 $\cdots \pi$ (phenyl) and $\mathrm{C} 11-\mathrm{H} 11 \cdots \mathrm{O} 4$ hydrogen bonds. The $\pi$ (triazole) $\cdots \pi$ (nitrophenyl), $\pi$ (phenyl) $\cdots \pi$ (nitrophenyl) and $\mathrm{N} 7-\mathrm{O} 4 \cdots \pi$ (phenyl) interactions generate dimeric units, which are linked into single-molecule wide columns by the $\pi$ (triazole) $\cdots \pi$ (triazole) interactions. These singlemolecule wide columns are further linked into bi-molecule wide columns by the $\mathrm{C} 11-\mathrm{H} 11 \cdots \mathrm{O} 4$ hydrogen bonds (see Figure 7c). Overall, a three-dimensional array is produced.

\section{Compound $\left(3 \cdot 2 \mathrm{H}_{2} \mathrm{O}\right)$}

The intermolecular interactions in compound $\left(32 \mathrm{H}_{2} \mathrm{O}\right)$ are $\pi \cdots \pi$ stacking interactions and $\mathrm{O}-\mathrm{H} \cdots \mathrm{X}(\mathrm{X}=\mathrm{O}$ and $\mathrm{N}), \mathrm{N}-\mathrm{H} \cdots \mathrm{O}$ and $\mathrm{C}-\mathrm{H} \cdots \mathrm{O}$ hydrogen bonds (Table 4). As expected, the two water molecules are strongly involved in the supramolecular arrangements. A sheet containing 


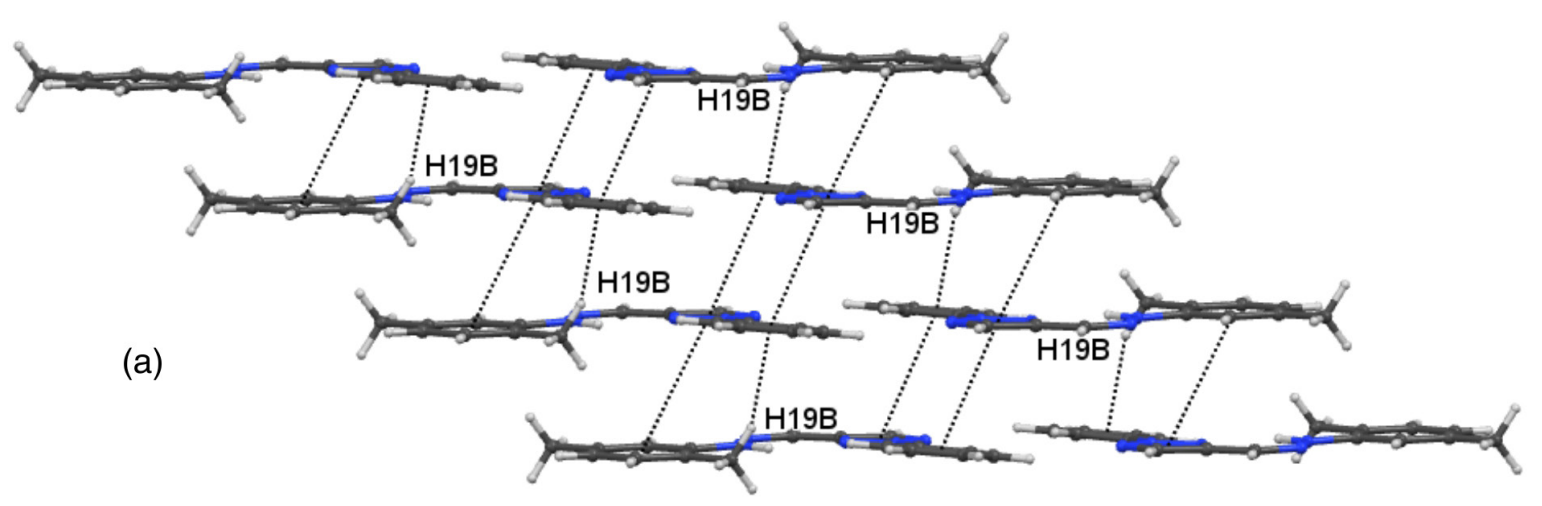

(b)

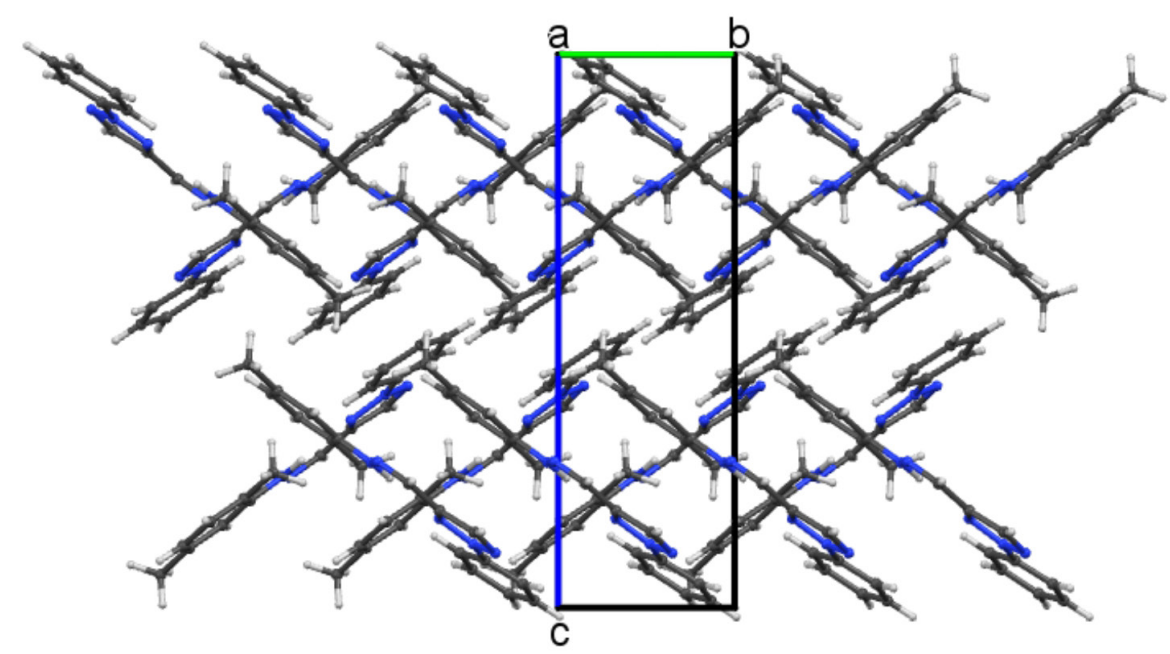

Figure 6. Compound 2a. (a) Part of a two-molecular wide column of molecules of 2a generated from $\pi($ triazole $) \cdots \pi($ phenyl- $a), \pi($ triazole $) \cdots \pi($ phenyl- $b$ ) and by $\mathrm{C}-\mathrm{H} \cdots \pi($ phenyl- $a$ ) interactions, where phenyl $-a$ and phenyl- $b$ refer to the phenyl group attached to the triazole and the other phenyl group, respectively; (b) a view, looking down the a-axis of the orientations of the different columns passing through the unit cell.

molecules of $\mathbf{3}$ and water, with oxygen atom, OW1, is generated from combinations of $\pi$ (triazolyl) $\cdots \pi($ phenyl), $\pi($ triazolyl $) \cdots \pi$ (pyridinyl) and $\pi$ (phenyl) $\cdots \pi$ (pyridinyl)

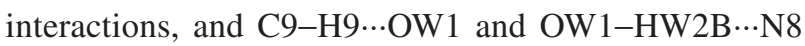
hydrogen bonds, as illustrated in Figure 8a. Molecules in each layer of the sheet are linked by C9-H9...OW1 and OW1-HW2B $\cdots \mathrm{N} 8$ hydrogen bonds, and layers are linked by the three different $\pi \cdots \pi$ interactions. The two water molecules make very different connections to other molecules, as shown in Figures $8 \mathrm{~b}$ and $8 \mathrm{c}$. There are seven short contacts to the water molecule, HW1A-OW2-HW2A (Figure $8 \mathrm{~b}$ ), but there are only four short contacts to the other water molecule, HW2A-OW1-HW2B (Figure 8c). Such contacts to the watermolecules generate various rings of atoms. However, the most interesting ring present in $\left(32 \mathrm{H}_{2} \mathrm{O}\right)$ is the $\mathrm{R}_{4}^{4}(8)$ ring generated from four water molecules, two of each HW1A-OW2-HW2A and HW2A-OW1-HW2B, see Figure 8d. As shown in Figure $8 \mathrm{~d}$, the water molecules in the tetrameric rings make short contacts with various atoms in $\mathbf{3}$. Overall, a three-dimension array is formed, see Figure 8e.
The hydrogen bonding interactions between the water molecules and molecule of $\mathbf{3}$ clearly stabilize the $E_{C(O) N H} / E_{C=N}$ arrangement about the $\mathrm{C}(\mathrm{O})-\mathrm{NH}-\mathrm{N}=\mathrm{CH}$-aryl fragment in $\left(3 \cdot 2 \mathrm{H}_{2} \mathrm{O}\right)$.

\section{Conclusions}

The significance of the classical intramolecular hydrogen bonds in the molecular conformations is very pronounced in this study. The formations of (Z)-configurations about the $\mathrm{C}=\mathrm{N}$ bonds in 1a and $\mathbf{2 a}$ arise from the stabilizing presence of intramolecular

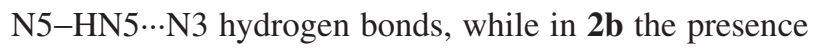
of intramolecular N5-HN5 ‥O1 hydrogen bonds, in lieu of potential N5-HN5 $\cdots \mathrm{N} 3$ hydrogen bonds, reinforces the $(E)$-geometry. An $E_{C(O) N H} / E_{C=N}$ arrangement about the $\mathrm{C}(\mathrm{O})-\mathrm{NH}-\mathrm{C}=\mathrm{N}$ fragment, and an interesting $\mathrm{R}_{4}^{4}(8)$ ring composed of four hydrate molecules, are features of the crystal structure of the hydrated acylhydrazone, $\left(\mathbf{3} \cdot 2 \mathbf{H}_{2} \mathbf{O}\right)$.

As found in this study, significant $\pi \cdots \pi$ interactions are exhibited by compounds $\mathbf{2} \mathbf{a}$ and $\mathbf{2} \mathbf{b}$, but not by the 

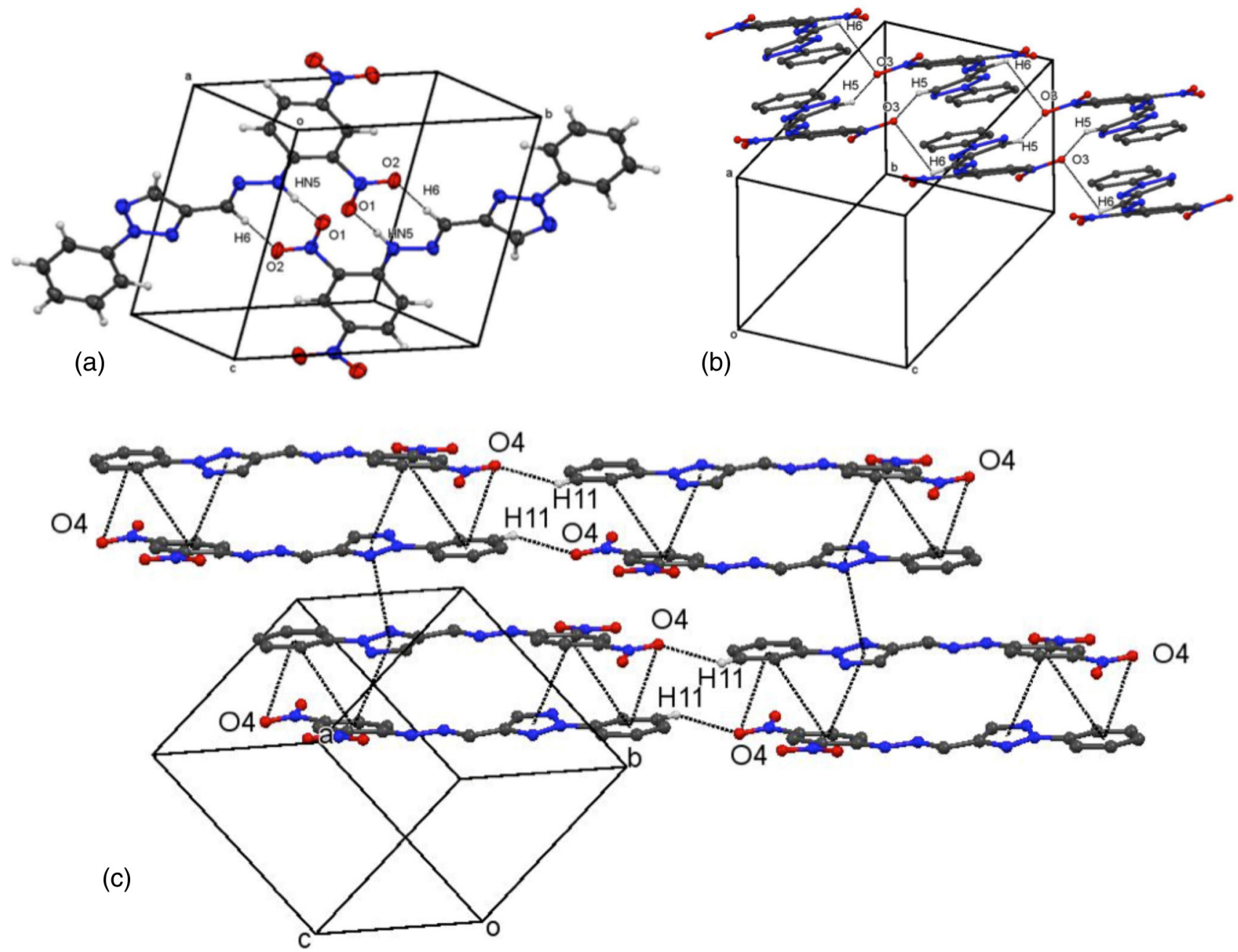

Figure 7. Compound 2b. (a) A centrosymmetric dimer generated from pairs of $\mathrm{N} 5-\mathrm{HN} 5 \cdots \mathrm{O} 1$ and $\mathrm{C} 6-\mathrm{H} 6 \cdots \mathrm{O} 2$ intermolecular hydrogen bonds: also indicated

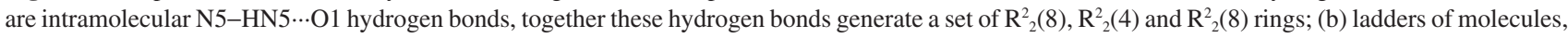
containing $\mathrm{R}_{2}{ }_{2}(24)$ and $\mathrm{R}_{2}^{4}(24)$ rings, are generated from the combination of $\mathrm{C} 5-\mathrm{H} 5 \cdots \mathrm{O} 3$ and $\mathrm{C} 6-\mathrm{H} 6 \cdots \mathrm{O} 3$ intermolecular hydrogen bonds; (c) part of a sheet of molecules generated from $\pi$ (triazole) $\cdots \pi($ nitrophenyl), $\pi$ (phenyl) $\cdots \pi($ nitrophenyl), $\pi$ (triazole) $\cdots \pi($ triazole) and N7-O $\cdots \cdots \pi($ phenyl) interactions and $\mathrm{C} 11-\mathrm{H} 11 \cdots \mathrm{O} 4$ intermolecular hydrogen bonds. Intermolecular interactions are drawn as thin dashed lines. Symmetry operations are listed in Table 4.

least planar molecule, 1a. In contrast, the only important intermolecular interactions in $\mathbf{1 a}$ are $\mathrm{C}-\mathrm{H} \cdots \pi$ interactions. Are these differences between 1a, on one hand, and 2a and $\mathbf{2 b}$, on the other, consequences of compound 1a being an $1 H-1,2,3$-triazole compound, while $\mathbf{2} \mathbf{a}$ and $\mathbf{2} \mathbf{b}$ are $2 H-1,2,3-$ triazole derivatives? To effectively answer these questions, further structures of related hydrazonyl derivatives of 1,2,3-triazoles need to be determined.

Moreover, there appears to be no obvious reason why 1a cannot adopt a near planar configuration. Other points to be considered are the influences of steric effects or the position of substituents. Compound 1a has no substituents in either the two phenyl rings, while both $\mathbf{2} \mathbf{a}$ and $\mathbf{2 b}$ have ortho- and para-substituents in the phenyl ring (C13-C18). The other $1 H-1,2,3$-triazole compound mentioned in this article, $\mathbf{1 b},{ }^{13}$ has ortho chloro substituents in both phenyl rings, and does exhibit a much smaller dihedral angle between the two phenyl rings than does 1a, but is still not planar (Table 3). As in 1a, no $\pi \cdots \pi$ interactions are exhibited by $\mathbf{1} \mathbf{b}$, but the number of different $\mathrm{C}-\mathrm{H} \cdots \pi$ intermolecular interactions is reduced to one. The most important intermolecular interaction in $\mathbf{1 b}$ is the classical intermolecular $\mathrm{N}$ (hydrazine) $-\mathrm{H} \cdot \cdots \mathrm{N}$ (triazole) hydrogen bonds, with less important interactions being $\mathrm{C}-\mathrm{H} \cdots \mathrm{Cl}$ and $\mathrm{N}$ (hydrazine) $-\mathrm{H} \cdots \mathrm{Cl}$ hydrogen bonds. This prompts the question: does the presence of substituents in the phenyl rings reduce or even prevent $\mathrm{C}-\mathrm{H} \cdots \pi$ interactions in $\mathbf{2 a}$ and $\mathbf{2} \mathbf{b}$, which thus results in different sets of intermolecular interactions being taken up? The answer awaits further study.

\section{Supplementary Information}

Full details of the crystal structure determinations in cif format are available in the online version as Supplementary 
(a)
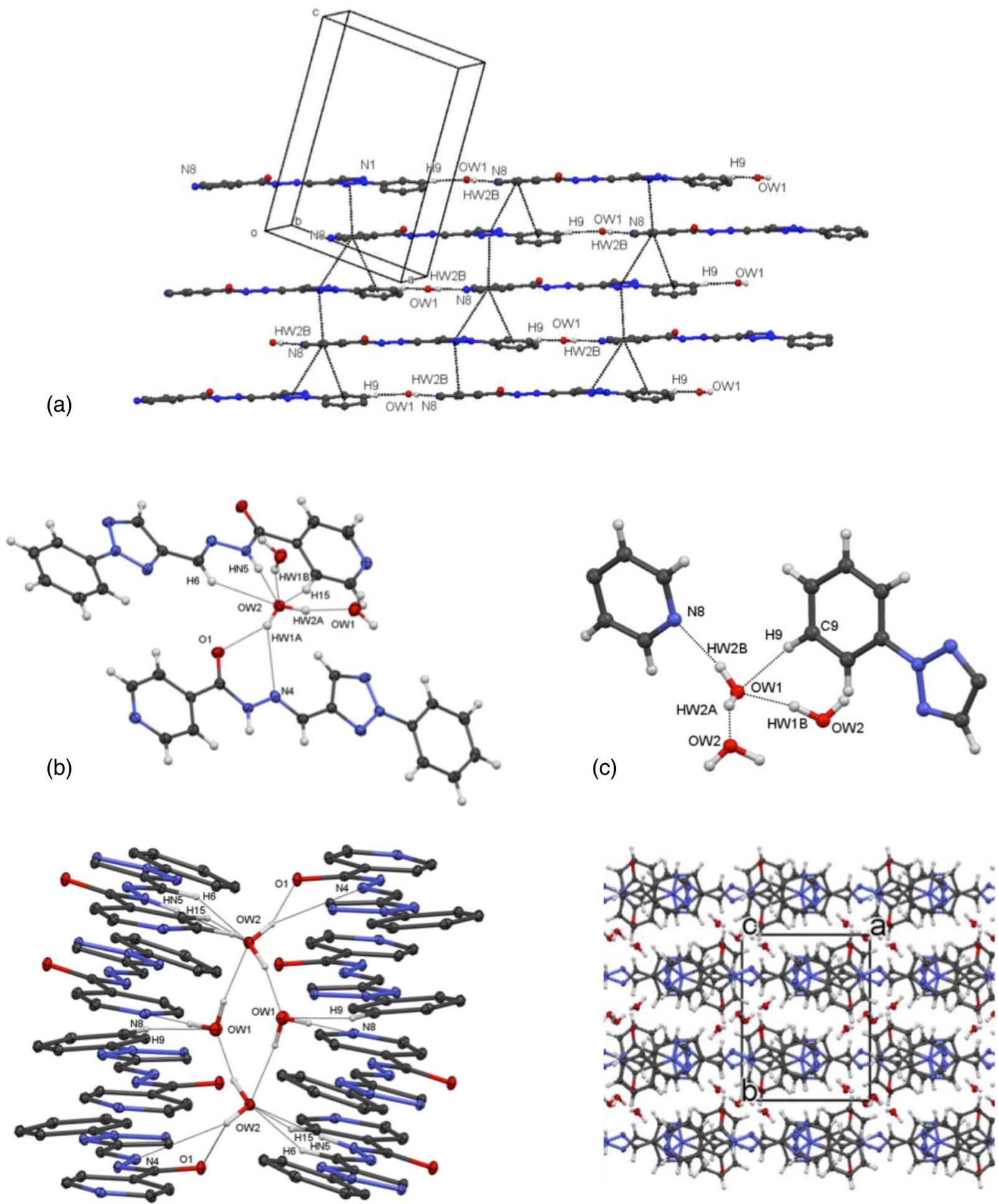

(d)

(e)

Figure 8. Compound $\left(32 \mathrm{H}_{2} \mathrm{O}\right)$. (a) A sheet of $\mathbf{3}$ and hydrate molecules (with OW1) is generated from combinations of $\pi($ triazolyl) $\cdots \pi(\mathrm{phenyl})$,

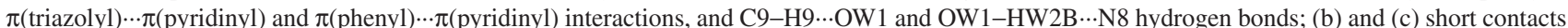
to the hydrate molecules, HW1A-OW2-HW2A and HW2A-OW1-HW2B, respectively; (d) a R ${ }_{4}(8)$ ring generated from four hydrate molecules, showing contacts with molecules 3; (e) packing of the molecules looking down the c-axis. Table 4 lists the symmetry operations. The intermolecular interactions are drawn as thin dashed lines.

Information, at http://jbcs.sbq.org.br, and have also been deposited with the Cambridge Crystallographic Data Centre with deposition numbers, 1434781, 1434786, 1434776 and 1434783 for $\mathbf{1 a}, \mathbf{2 a}, \mathbf{2 b}$ and $\left(\mathbf{3} 2 \mathrm{H}_{2} \mathrm{O}\right)$, respectively. Copies of 
these can be obtained free of charge on written application to CCDC, 12 Union Road, Cambridge, CB2 1EZ, UK (fax: +44 1223 336033); on request by e-mail to deposit@ccdc. cam.ac.uk or by access to http://www.ccdc.cam.ac.uk.

\section{Acknowledgments}

The use of the NCS crystallography service at Southampton and the valuable assistance of the staff there are gratefully acknowledged. JLW thanks FAPERJ and CNPq (Brazil) for support. SMSVW and JLW thank PhD John N. Low for discussions.

\section{References}

1. Dehaen, W.; Bakulev, V. A., eds., In Topics in Heterocyclic Chemistry, vol. 40; Springer: Heidelberg, 2015.

2. Rachwal, S.; Katritzky, A. R. In Comprehensive Heterocyclic Chemistry, $3^{\text {rd }}$ ed.; Katritzy, A. R.; Ramsden, C. A.; Scriven, E. F. V.; Taylor, R. J. K., eds.; Elsevier: Oxford, 2008, p. 1.

3. Bellagamba, M.; Bencivenni, L.; Gontrani, L.; Guidoni, L.; Sadun, C.; Struct. Chem. 2013, 4, 933.

4. Ferreira, M. L. G.; Pinheiro, L. C. S.; Santos-Filho, A. O.; Peçanha, M. D. S.; Sacramento, C. Q.; Machado, V.; Ferreira, V. F.; Souza, T. M. L.; Boechat, N.; Med. Chem. Res. 2014, 23, 1501.

5. Jordão, A. K.; Afonso, P. P.; Ferreira, V. F.; de Souza, M. C.; Almeida, M. C.; Beltrame, C. O.; Paiva, D. P.; Wardell, S. M. S. V.; Wardell, J. L.; Tiekink, E. R.; Damaso, C. R.; Cunha, A. C.; Eur. J. Med. Chem. 2009, 44, 3777.

6. Himanshu; Tyagi, R.; Olsen, C. E.; Errington, W.; Parmar, V. S.; Prasad, A. K.; Bioorg. Med. Chem. 2002, 10, 963.

7. Boechat, N.; Ferreira, M. L.; Pinheiro, L. C.; Jesus, A. M.; Leite, M. M.; Júnior, C. C.; Aguiar, A. C.; de Andrade, I. M.; Krettli, A. U.; Chem. Biol. Drug. Des. 2014, 84, 325.

8. Ferreira, M. L.; de Souza, M. V. N.; Wardell, S. M. S. V.; Wardell, J. L.; Vasconcelos, T. R. A.; Ferreira, V. F.; Lourenço, M. C. S.; J. Carb. Chem. 2010, 29, 265.

9. Jordão, A. K.; Sathler, P. C.; Ferreira, V. F.; Campos, V. R.; de Souza, M. C.; Castro, H. C.; Lannes, A.; Lourenco, A.; Rodrigues, C. R.; Bello, M. L.; Lourenco, M. C.; Carvalho, G. S.; Almeida, M. C.; Cunha, A. C.; Bioorg. Med. Chem. 2011, $19,5605$.

10. Boechat, N.; Ferreira, V. F.; Ferreira, S. B.; Ferreira, M. L. G.; da Silva, F. C.; Bastos, M. M.; Costa, M. S.; Lourenço, M. C.; Pinto, A. C.; Krettli, A. U.; Aguiar, A. C.; Teixeira, B. M.; da Silva, N. V.; Martins, P. R.; Bezerra, F. A.; Camilo, A. L.; da Silva, G. P.; Costa, C. C.; J. Med. Chem. 2011, 54, 5988.

11. Lima-Neto, R. G.; Cavalcante, N. N.; Srivastava, R. M.; Mendonça Junior, F. J.; Wanderley, A. G.; Neves, R. P.; dos Anjos, J. V.; Molecules 2012, 17, 5882.
12. da Silva, I. F.; Martins, P. R.; da Silva, E. G.; Ferreira, S. B.; Ferreira, V. F.; da Costa, K. R.; de Vasconcellos, M. C.; Lima, E. S.; da Silva, F. C.; Med. Chem. 2013, 9, 1085.

13. Dai, Z. C.; Chen, Y. F.; Zhang, M.; Li, S. K.; Yang, T. T.; Shen, L.; Wang, J. X.; Qian, S. S.; Zhu, H. L.; Ye, Y. H.; Org. Biomol. Chem. 2015, 13, 477.

14. da Silva, F. C.; de Souza, M. C.; Frugulhetti, I. I.; Castro, H. C.; Souza, S. L.; de Souza, T. M.; Rodrigues, D. Q.; Souza, A. M.; Abreu, P. A.; Passamani, F.; Rodrigues, C. R.; Ferreira, V. F.; Eur. J. Med. Chem. 2009, 44, 373.

15. Weide, T.; Saldanha, S. A.; Minond, D.; Spicer, T. P.; Fotsing, J. R.; Spaargaren, M.; Frère, J.-M.; Bebrone, C.; Sharpless, K. B.; Hodder, P. S.; Fokin, V. V.; ACS Med. Chem. Lett. 2010, 1, 150.

16. Rogawski, M. A.; Epilepsy Res. 2006, 69, 273.

17. Jordão, A. K.; Ferreira, V. F.; Souza, T. M. L.; Faria, G. G.; Machado, V.; Abrantes, J. L.; de Souza, M. C. B. V.; Cunha, A. C.; Bioorg. Med. Chem. 2011, 19, 1860.

18. Shafi, S.; Alam, M. M.; Mulakayala, N.; Mulakayala, C.; Vanaja, G.; Kalle, A. M.; Pallu, R.; Alam, M. S.; Eur. J. Med. Chem. 2012, 49, 324.

19. Banday, A. H.; Shameem, S. A.; Ganai, B. A.; Org. Med. Chem. Lett. 2012, 2, 13.

20. Sumangala, V.; Poojary, B.; Chidananda, N.; Fernandes, J.; Kumari, N. S.; Arch. Pharm. Res. 2010, 33, 1911.

21. Senger, M. R.; Gomes, L. C.; Ferreira, S. B.; Kaiser, C. R.; Ferreira, V. F.; Silva-Jr., F. P.; ChemBioChem 2012, 13, 1584.

22. Périon, R.; Ferrières, V.; Garcia-Moreno, M. I.; Mellet, C. O.; Duval, R.; Fernández, J. M. G.; Plusquellec, D.; Tetrahedron 2005, 61, 9118.

23. Zhou, Y.; Zhao, Y.; O’Boyle, K. M.; Murphy, P. V.; Bioorg. Med. Chem. Lett. 2008, 18, 954.

24. Gonzaga, D.; Senger, M. R.; da Silva, F. C.; Ferreira, V. F.; Silva-Jr., F. P.; Eur. J. Med. Chem. 2014, 74, 461.

25. Otwinowski, Z.; Minor, W.; Methods in Enzymology, Vol. 276, Macromolecular Crystallography, Part A; Carter, C. W.; Sweet, R. M., eds.; Academic Press: New York, 1997, p. 307-326.

26. Hooft, R. W. W.; Nonius, B. V.; COLLECT, Data Collection Software; Delft: The Netherlands, 1998.

27. Sheldrick, G. M.; SADABS Version 2007/2; Bruker AXS Inc.: Madison, Wisconsin, 2007.

28. MERCURY 3.3.1 Cambridge Crystallographic Data Centre, UK.

29. Sheldrick, G. M.; Acta Crystallogr. 2008, A64, 112.

30. Spek, A. L.: J. Appl. Crystallogr. 2003, 36, 7.

31. McArdle, P.; Oscail - Windows Software for Crystallography and Molecular Modelling; National University of Ireland: Galway, 2016.

32. Cardoso, L. N.; Bispo, M. L.; Kaiser, C. R.; Wardell, J. L.; Wardell, S. M.; Lourenço, M. C.; Bezerra, F. A.; Soares, R. P.; Rocha, M. N.; de Souza, M. V.; Arch. Pharm. Chem. Life Sci. 2014, 347, 432. 
33. Lopes, A. B.; Miguez, E.; Kümmerle, A. E.; Rumjanek, V. M.; Fraga, C. A.; Barreiro, E. J.; Molecules 2013, 18, 11683.

34. da Silva, Y. K.; Reyes, C. T.; Rivera, G.; Alves, M. A.; Barreiro, E. J.; Moreira, M. S.; Lima, L. M.; Molecules 2014, 19, 8456.

35. Palla, G.; Predieri, G.; Domiano, P.; Vignali, C.; Turner, C. W.; Tetrahedron 1986, 42, 3649.

36. Costa, M. S.; Boechat, N.; Ferreira, V. F.; Wardell, S. M. S. V.; Skakle, J. M. S.; Acta Crystallogr. Sect. E 2006, E62, o1925.

37. Vinutha, N.; Madan Kumar, S.; Nithinchandra; Balakrishna, K.; Lokanath, N. K.; Revannasiddaiah, D.; Acta Crystallogr. Sect. E 2013, E69, o1724.

38. Desiraju, G. R.; Angew.Chem., Int. Ed. 2007, 46, 8342.
39. Tiekink, E. R. T.; Zukerman-Schpector, J., eds., In The Importance of $\pi$-Interactions in Crystal Engineering: Frontiers in Crystal Engineering, 2 ${ }^{\text {nd }}$ ed.; Wiley: Singapore, 2012.

40. Tiekink, E. R. T. In Supramolecular Chemistry: from Molecules to Nanomaterials; Steed, J. W.; Gale, P. A., eds.; John Wiley \& Sons Ltd: Chichester, UK, 2012, p. 2791.

41. Huang, L.; Massa, L.; Karle, J.; Proc. Natl. Acad. Sci. 2008, 105, 13720.

42. Bernstein, J.; Davis, R. E.; Shimoni, L.; Chang, N. L.; Angew. Chem. Int. Ed. 1995, 34, 1555.

Submitted: November 24, 2015

Published online: April 27, 2016 